\title{
Validitas Konstruk Instrumen Kemampuan Berfikir Kritis Siswa Pada Pembelajaran Matematika di SMP
}

\author{
${ }^{1)}$ Mansyur, ${ }^{2)}$ Syahrul, ${ }^{3)}$ Akbar Iskandar \\ Email: mansyurunm@gmail.com, syahrulab@yahoo.co.id, akbar.iskandar06@gmail.com \\ ${ }^{1,2)}$ Fakultas Teknik, Universitas Negeri Makassar \\ ${ }^{3)}$ Teknik Informatika, STMIK AKBA
}

\begin{abstract}
ABSTRAK
Tujuan tulisan ini adalah mengembangkan instrument kemampuan berfikir kritis siswa pada pembelajaran matematika di Sekolah Menengah Pertama (SMP) yang memenuhi kriteria valid secara isi dan konstruk dan reliabel. Penelitian ini merupakan penelitian dan pengembangan atau Research and Develoment yang bertujuan untuk mengembangkan dan mendesain instrument penilaian diri pada mata pada pelajaran matematika dengan mengadopsi model R, D \& D (Havelock,1976). Penelitian ini dilaksanakan mulai bulan April 2016 sampai dengan bulan Juli 2016 di Kota Makassar dan Kabupaten Gowa Sulawesi Selatan. Jumlah siswa yang dijadikan sebagai sampel penelitian sebanyak 927 orang siswa kelas VII pada 4 SMP yang ada di Kota Makassar dan Kabupaten Gowa yaitu SMPN 1 Palangga, SMPN 7 Makassar, Madrasah Assa'diyah Makassar, dan SMP Muhammadiyah 3 Bontoala Makassar. Pengambilan sampel dilakukan dengan menggunakan teknik stratified random sampling (Krathwohl, 1998) yaitu teknik pengambilan sampel berdasarkan akreditasi sekolah. Keempat sekolah yang dipilih mewakili akreditasi A, B, C dan belum teraktreditasi.Teknik analisis data yang digunakan adalah Confirmatory Faktor Analisys (CFA) dengan program Lisrel. Hasil analisis CFA menunjukkan bahwa instrument yang dikembangkan memenuhi syarat valid dan reliable.
\end{abstract}

Kata kunci:Penilaian, CFA, Berifikir kritis,Valid dan reliabel . 


\begin{abstract}
The purpose of this paper is to development of instrument of students' critical thinking skills in learning mathematics in Junior High School (SMP) that meets the criteria valid content and constructive and reliable. This research is a research and development or Research and Develoment which aims to develop and design assessment instruments Self in the eyes of mathematics lessons by adopting model R, D \& D (Havelock, 1976). This research was conducted from April 2016 until July 2016 in Kota Makassar and Gowa regency of South Sulawesi. The number of students used as a sample of 927 students of grade VII in 4 junior high schools in Makassar and Gowa are SMPN 1 Palangga, SMPN 7 Makassar, Madrasah Assa'diyah Makassar, and SMP Muhammadiyah 3 Bontoala Makassar. Sampling is done by using stratified random sampling technique (Krathwohl, 1998) that is sampling technique based on school accreditation. The four selected schools represent A, B, C and accreditation accreditations. Data analysis technique used is Confirmatory Factor Analisys (CFA) with Lisrel program. The results of the CFA analysis show that the developed instruments are valid and reliable.
\end{abstract}

Keywordsi: CFA, critical thinking,valid and reliable.

\title{
A. Pendahuluan
}

Penelitian tentang kemampuan berfikir kritis pada mata pelajaran matematika pada tingkatan Sekolah Menengah Pertama (SMP) khususnya di Sulawesi Selatan masih jarang dilakukan, padahal salah satu Standar Kompetesi Lulusan untuk tingkat satuan pendidikan SMP menunjukkan bahwa kemampuan berpikir logis, kritis, kreatif dan inovatif, merupakan salah satu kemampuan belajar secara mandiri sesuai potensi yang dimilikinya, dan menunjukkan kemampuan menganalisis dan memecahkan masalah dalam kehidupan sehari-hari.

Kemampuan berpikir kritis merupakan suatu proses berfikir terusmenerus, aktif dan teliti yang bertujuan untuk membuat keputusan rasional bukan untuk mencari jawaban semata, tetapi yang terlebih utama adalah mempertanyakan jawaban, fakta, atau informasi yang ada. Menyikapi masalah yang timbul dalam pendidikan matematika dan harapan yang ingin dicapai dalam pembelajaran matematika, maka diperlukan upaya yang inovatif untuk memperbaiki dan meningkatkan mutu pembelajaran matematika melalui perbaikan proses pembelajaran dengan menggali infromasi kemampuan berfikir 
kritis siswa terlebih dahulu. Moore dan Parker (1986) juga menjelaskan bahwa berpikir kritis membutuhkan banyak keterampilan, termasuk keterampilan mendengar dan membaca dengan hati-hati, mencari dan mendapatkan asumsiasumsi yang tersembunyi, dan menjajaki konsekuensi dari suatu pernyataan.

Lebih lanjut Ennis (1993) mejelaskan bahwa tujuan dari penilaian berfikir kritis pada siswa yaitu: (1) mendiagnosa tingkat kemampuan berfikir kritis siswa(diagnosing the levels of students critical thinking), (2) memberikan umpan balik terkait kemampuan siswa dalam berfikir kritis (giving students feedback about their critical thinking prowess), (3) memotivasi siswa untuk menjadi lebih baik dalam berpikir kritis serta masih banyak yang lainnya. Pendapat Ennis tersebut memberi gambaran bahwa informasi tentang kemampuan berpikir kritis siswa menjadi sesuatu yang sangat sangat diperlukan oleh seorang guru dalam proses pembelajaran. Pengetahuan awal guru akan kemampuan berpikir kritis para siswa akan memberikan arahan dan petunjuk bagi guru tersebut dalam upaya menyiapkan strategi pembelajaran yang tepat sehingga informasi yang disampaikan dalam pembelajaran lebih efektif dan efisien diterima para siswa.

Namun kenyataan menunjukkan bahwa kemampuan berpikir kritis matematis siswa-siswa di Indonesia khususnya siswa SMP Kota Makassar dan kabupaten Gowa Sulawesi Selatan masih belum memuaskan. Hal ini dibuktikan dengan hasil ujian nasional tahun 2016 peringkat 1 direbut oleh daerah Bone dengan rata-rata nilai UN 78,13. Sedangkan peringkat 2 diraih Kabupaten Soppeng dengan rata-rata nilai 69,32. Peringkat 3 Kabupaten Bulukumba dengan rata-rata nilai 69,05 .

Melihat kenyataan yang ada, maka perlu dilakukan usaha untuk mengungkap permasalahan yang terjadi pada siswa dengan melakukan berbagai inovasi pembelajaran untuk memperbaiki dan meningkatkan hasil ujian nasional terhusus pada hasil belajar matematika di kelas dengan terlebih dahulu menggali kemampuan berfikir kritis siswa.Untuk itu, peneliti tertarik untuk melakukan pengembangan instrumen penilaian berfikir kritis yang dapat digunakan untuk 
mengungkap kemampuan berfikir kritis seluruh siswa pada mata pelajaran matematika di SMP.

\section{B. Tinjauan Pustaka}

Keterlibatan siswa dalam proses penilaian diri mereka sendiri akan membawa dampak positif terhadap perkembangan psikologi dan berpikir siswa itu sendiri. Mereka mengetahui kekuatan dan kelemahan merupakan sesuatu yang dapat mendorong dan memotivasi untuk selalu meningkatkan dan memperbaikinya, dengan sendirinya mengajarkan siswa menyadari pentingnya rasa tanggungjawab, kejujuran, dan kerja keras dalam meningkatkan kualitas dirinya.

Ketika siswa telah memahami dengan baik apa yang menjadi kebutuhan nyata mereka dalam penilaian dan pembelajaran, maka dalam pemikiran mereka akan muncul kesadaran, rasa tanggung jawab, keinginan untuk kerja keras dan pembuktian diri, bahwa mereka sesungguhnya mampu melakukan sesuatu yang terbaik jika mendapat kepercayaan penuh dari guru mereka. Hal ini merupakan sesuatu yang baru dan sangat diharapkan oleh para siswa, terutama untuk memperbaiki dan mengembangkan dimensi berpikir siswa yang meliputi metakognisi, berpikir kritis dan kreatif, proses berpikir, alur berpikir, dan hubungan antara isi area pengetahuan dengan berpkir (Robert J.Marzano et al., 1988: 4).

Umumnya instrumen dikatakan sebagai alat yang memenuhi persyaratan akademis, sehingga dapat digunakan sebagai alat untuk mengukur suatu objek ukur atau mengumpulkan data mengenai suatu variable. Dalam bidang penelitian, instrumen diartikan sebagai alat untuk mengumpulkan data mengenai variabelvariabel penelitian untuk kebutuhan penelitian, sedangkan dalam bidang pendidikan instrumen penilaian digunakan untuk mengukur prestasi belajar mahasiswa, faktor-faktor yang diduga mempunyai hubungan atau berpengaruh terhadap hasil belajar, perkembangan hasil belajar siswa, keberhasilan proses belajar mengajar dosen, dan keberhasilan pencapaian suatu program tertentu. 
Nitko \& Brookhart (2007: 4) penilaian didefinisikan sebagai suatu proses untuk mendapatkan informasi yang digunakan untuk membuat keputusan tentang siswa; kurikulum, program dan kebijakan pendidikan. Sedangkan Sudrajat (2008) menjelaskan bahwa penilaian (assessment) merupakan penerapan beragam alat penilaian untuk memperoleh informasi tentang sejauh mana hasil belajar peserta didik atau ketercapaian kompetensi (rangkaian kemampuan) peserta didik.

Jadi penilaian adalah hasil pengukuran dan penentuan pencapaian hasil belajar, sementara evaluasi adalah penentuan nilai suatu program dan penentuan pencapaian tujuan suatu program.Ada dua istilah terkait dengan konsep penilaian (assessment), yaitu pengukuran (measurement) dan evaluasi (evaluation. Pengukuran adalah proses penetapan angka terhadap suatu gejala menurut aturan tertentu. Sedangkan evaluasi adalah penilaian yang sistematik tentang manfaat suatu objek atau pengambilan keputusan akhir.

Ruggiero (1998) mengartikan berpikir sebagai suatu aktivitas mental untuk membantu memformulasikan atau memecahkan suatu masalah, membuat suatu keputusan, atau memenuhi hasrat keingintahuan (fulfill a desire to understand). Pendapat ini menunjukkan bahwa ketika seseorang merumuskan suatu masalah, memecahkan masalah, ataupun ingin memahami sesuatu, maka ia melakukan suatu aktivitas berpikir.

Berpikir sebagai suatu kemampuan mental seseorang dapat dibedakan menjadi beberapa jenis, antara lain berpikir logis, analitis, sistematis, kritis, dan kreatif. Berpikir logis dapat diartikan sebagai kemampuan berpikir siswa untuk menarik kesimpulan yang sah menurut aturan logika dan dapat membuktikan bahwa kesimpulan itu benar (valid) sesuai dengan pengetahuan-pengetahuan sebelumnya yang sudah diketahui.

Seringkali pengajaran berpikir kritis diartikan sebagai problem solving, meskipun kemampuan memecahkan masalah merupakan sebagian dari kemampuan berpikir kritis.Ennis (1993:2) mengemukakan definisi berpikir kritis yang berbunyi "critical thinking isreasonable reflective thinking focused on deciding what to believe or do.”Memiliki makna bahwa berpikir kritis adalah 
berpikir secara beralasan dan reflektif dengan menekankan pembuatan keputusan tentang apa yang harus dipercayai atau dilakukan”.

Selanjutnya dijelaskan bahwa tujuan dari penilaian berfikir kritis pada siswa yaitu: Mendiagnosa tingkat kemampuan siswa berfikir kritis (diagnosing the levels of students critical thinking), Memberikan umpan balik terkait kemampuan siswa dalam berfikir kritis (giving students feedback about their critical thinking prowess), Memotivasi siswa untuk menjadi lebih baik dalam berpikir kritis serta masih banyak yang lainnya.

Berpikir kritis merupakan kegiatan memproses informasi yang akurat sehingga dapat dipercaya, logis, dan kesimpulannya meyakinkan, dan dapat membuat keputusan yang bertanggung jawab.Seseorang yang berpikir kritis dapat bernalar logis dan membuat kesimpulan yang tepat.Kemampuan berpikir kritis memiliki posisi yang sangat penting, karena dalam kehidupan sehari-hari misalnya, cara seseorang mengarahkan hidupnya bergantung pada pernyataan yang dipercayainya dan pernyataan yang diterimanya.

Penalaran adalah proses kemampuan berpikir seseorang untuk mendapatkan suatu pengetahuan baru dengan cara melogikakan konsep-konsep yang diketahuinya berdasarkan bukti-bukti yang ada dan mengkontradiksikannya dengan pengetahuan yang sebelumnya. Penalaran juga merupakan semua hubungan antara pengalaman dan pengetahuan yang digunakan seseorang untuk menjelaskan apa yang dilihat, dipikirkan dan disimpulkan. Jadi Penalaran berasal dari kemampuan berpikir seseorang.

Dalam pembelajaran matematika dengan pemecahan masalah siswa dituntut untuk menggali dan menunjukkan kemampuan berpikir kritisnya mulai dari memahami masalah, merencanakan pemecahan, melaksanakan rencana pemecahan, dan melihat kembali kembali pemecahan masalah yang telah dilaksanakan.Moore dan Parker (1986: 5) juga menjelaskan bahwa berpikir kritis membutuhkan banyak keterampilan, termasuk keterampilan mendengar dan membaca dengan hati-hati, mencari dan mendapatkan asumsi-asumsi yang tersembunyi, dan menjajaki konsekuensi dari suatu pernyataan. 
Ennis (1993:2) mejelaskan bahwa tujuan dari penilaian berfikir kritis pada siswa yaitu:

a. Mendiagnosa tingkat kemampuan siswa berfikir kritis (diagnosing the levels of students critical thinking)

b. Memberikan umpan balik terkait kemampuan siswa dalam berfikir kritis (giving students feedback about their critical thinking prowess)

c. Memotivasi siswa untuk menjadi lebih baik dalam berpikir kritis (motivating students to be better at critical thinking)

d. Informasi bagi guru tentang keberhasilan siswa mengajar siswa untuk berpikir kritis (informing teachers about the success of their efforts to teach students to think critically)

e. Melakukan penelitian tentang berpikir kritis untuk menjawab pertanyaan dan masalah yang ada (doing research about critical thinking instructional question and issue)

f. Memberikan bantuan dalam pengambilan keputusan apakah seorang siswa bisa di memasukkan ke dalam program pendidikan tertentu (providing help in deciding whether a student should enter an educational program)

g. Memberikan informasi bagi kepala sekolah terkait kemampuan siswanya dalam berfikir kritis (providing information for holding schools accountable for the critical thinking prowess of their student)

Selain itu (Cindy L. Lynch \& Susan K. Wolcott, 2001:2) menjelaskan bahwa Langkah-langkah yang dapat digunakan untuk membantu siswa berpikir lebih baik dalam menyelesaikan masalah adalah seperti berikut:

Step 1 - identify the problem, relevant information, and uncertainties;

Step 2 - explore interpretations and connections;

Step 3 - prioritize alternatives and communicate conclusions; and

Step 4 - integrate, monitor, and refine strategies for re-addressing the problem.

Lebih lanjut Norris \& Ennis 1989(Perkins, C., \& Murphy, E., 2006:299) mengidentifikasi 12 indikator berpikir kritis yang dikelompokannya dalam lima besar aktivitas sebagai berikut: 
a. Memberikan penjelasan sederhana, yang berisi; memfokuskan pertanyaan, menganalisis pertanyaan dan bertanya, serta menjawab pertanyaan tentang suatu penjelasan atau pernyataan.

b. Membangun keterampilan dasar, yang terdiri atas mempertimbangkan apakah sumber dapat dipercaya atau tidak dan mengenai serta mempertimbangkan suatu laporan hasil observasi.

c. Menyimpulkan yang terdiri atas kegiatan mendeduksi atau mempertimbangkan hasil deduksi, meninduksi atau mempertimbangkan hasil induksi, dan membuat serta menentukan nilai pertimbangan.

d. Memberikan penjelasan lanjut, yang terdiri atas mengidentifikasi istilahistilah dan deinisi pertimbangan dan juga dimensi, serta mengidentifikasi asumsi.

e. Mengatur strategi dan teknik, yang terdiri atas menentukan tindakan dan berinteraksi dengan orang lain

Rendahnya kemampuan interpretasi, analisis, evaluasi, inferensi, explanasi, dan self regulation menandakan kemampuan berpikir kritis siswa tergolong rendah (Fithriyah, Sa'dijah, \& Sisworo, 2016:587).Selanjutnya beberapa keterampilan berpikir yang berkaitan dengan berpikir kritis seperti membandingkan, membedakan, memperkirakan, menarik kesimpulan, mempengaruhi, generalisasi, spesialisasi, mengklasifikasi, mengelompokkan, mengurutkan, memprediksi, memfalidasi, membuktikan, menghubungkan, menganalis, mengevaluasi dan membuat pola.

Lebih lanjut, seorang siswa dikatakan mampu berpikir kritis jika memiliki kemampuan dalam:

a. Memilih kata-kata dan frase yang penting dalam sebuah pernyataan dan akan didefinisikan secara hati-hati.

b. Membutuhkan keyakinan untuk mendukung suatu kesimpulan ketika dia dipaksa untuk menerimanya

c. Menganalisa keyakinan itu dan membedakan suatu fakta dari asumsi 
d. Menentukan asumsi penting yang tertulis dan yang tidak tertulis untuk kesimpulan tersebut.

e. Mengevaluasi asumsi-asumsi ini, menerima beberapa saja dan menolak lainnya.

f. Mengevaluasi pendapat, menerima atau menolak kesimpulan.

g. Terus menerus memeriksa kembali asumsi yang telah dilakukan dan percaya sebelumnya.

Krulik \& Rudnick (1999) menambahkan bahwa kegiatan yang dapat mengembangkan keterampilan berpikir kritis siswa yaitu dengan menjawab pertanyaan-pertanyaan inovatif, seperti: Adakah Cara lain? (What's another way?), Bagaimana jika...? (What if ...?), Manakah yang salah? (What's wrong?), dan Apakah yang akan dilakukan? (What would you do?).

\section{Metode Penelitian}

Penelitian ini merupakan penelitiandan pengembangan atau Research and Develoment yang bertujuan untuk mengembangkan dan mendesain instrument penilaian diri pada mata pada pelajaran matematika dengan mengadopsi model R, D \& D (Havelock,1976).Penelitian ini dilaksanakan mulai bulan April 2016 sampai dengan bulan Juli 2016 di Kota Makassar dan Kabupaten Gowa Sulawesi Selatan. Jumlah siswa yang dijadikan sebagai sampel penelitian sebanyak 927 orang siswa kelas VII pada 4 SMP yang ada di Kota Makassar dan Kabupaten Gowa yaitu SMPN 1 Palangga, SMPN 7 Makassar, Madrasah Assa'diyah Makassar, dan SMP Muhammadiyah 3 Bontoala Makassar. Pengambilan sampel dilakukan dengan menggunakan teknik stratified random sampling(Krathwohl, 1998) yaitu teknik pengambilan sampel berdasarkan akreditasi sekolah. Keempat sekolah yang dipilih mewakili akreditasi A, B, C dan belum teraktreditasi.

Instrumen kecenderungan kemampuan berpikir kritis siswa pada pembelajaran matematika yang terdiri atas 5 (lima) indicator dan 39 butir. Indikator yang membangun angket tersebut yaitu memberikan penjelasan 
sederhana, membangun keterampilaan dasar, membuat inferensi, memberikan penjelasan lebih lanjut, dan mengatur strategi dan teknik dalam penyelesaian soalsoal matematika. Angket yang digunakan dikembangkan oleh tim peneliti dan telah diuji validitas isi melalui focus group discussion yang melibatkan 3 orang pakar. Ujicoba validitas konstruk dan reliabilitas konsruk dilakukan terhadap 800 orang responden dan dianalisis dengan menggunakan analisis factor konfirmatori. Semua butir angket telah memenuhi kriteria validitas konstruk yaitu memiliki factor loading $>0.3$ dan reliabilitas sebesar 0.92 lebih besar dari kriteria 0.7 (Linn, 1989).

\section{Hasil Penelitian dan Pembahasan}

Data hasil pengembangan dan penerapan instrument penilaian diri terkait dengan kemampuan berfikir kritispada mata pelajaran matematika dapat diuraikan seperti berikut:

Model penilaian dikatakan valid apabila model tersebut mampu menghasilkan penilaian seperti apa yang hendak dinilai. Reliabel adalah kekonsistenan suatu alat ukur dalam mengukur sesuatu.Berdasarkan hasil analisis faktor ditemukan bahwa model secara teoritis sesuai dengan data empiris (fit) namun pada tahap analisis pertama masih terdapat butir yang tidak memenuhi criteria valid dan hasil analisis dapat dilihat pada tampilan diagram lintasan Model kemampuan berfikir kritis (Standardized Solution) seperti pada Gambar 1.1 dengan indikator H-L (Memberikan penjelasan sederhana, Membangun keterampilan dasar, Membuat inferensi, Memberikan penjelasan lebih lanjut, Mengatur strategi dan teknik). 


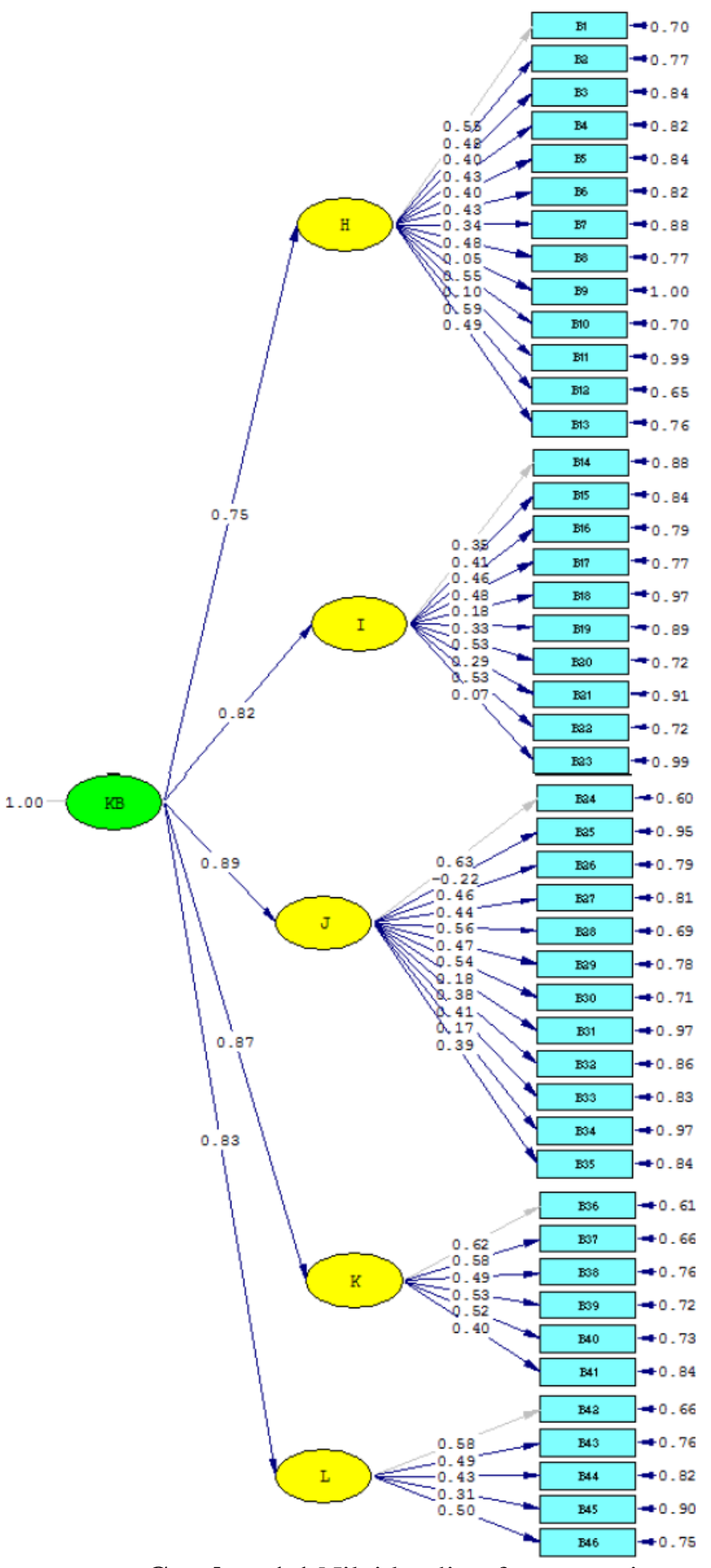

Gambar 1.1 Nilai loading factor masing-masing indikator Analisis tahap I 
Mencermati informasi yang disajikan pada Gambar 1.1.tampak bahwa factor loading lebih besar dari 0,3 untuk setiap butir instrument yang membangun indicator $\mathrm{H}$ sampai indikator L. Dengan demikian 7 butir instrument tidak memenuhi kriteria valid untuk mengukur faktornya. Sehingga harus dianalisis kembali dengan syarat mengeluarkan butir yang tidak valid (butir 9; butir 11; butir 18;butir 23; butir 25; butir 31; butir 34;)SedangkanModel secara teoritis telah sesuai dengan data empiris.Criteria untuk menguji Goodness of Fit model yaitu RMSEA, PNFI dan IFI, Seperti yang disajikan pada Tabel 1.1.

Tabel 1.1.Statistic dan Criteria Fit Model

\begin{tabular}{|c|c|c|c|c|}
\hline No. & Statistik & $\begin{array}{c}\text { Hasil } \\
\text { perhitungan }\end{array}$ & Kriteria 'fit” & Keterangan \\
\hline 1 & $\begin{array}{c}\text { Minimum fit function } \\
\text { chi-square }\left(\chi^{2}\right)\end{array}$ & $\begin{array}{c}3403.83 \\
(\mathrm{P}=0.0)\end{array}$ & $\mathrm{p}>0.05$ & Tdk fit \\
\hline 2 & RMSEA & 0.059 & $<0.08$ & Fit \\
\hline 3 & $\begin{array}{c}\text { Root Mean Square } \\
\text { Residual (RMR) }\end{array}$ & 0.043 & $\leq 0,10$ & Fit \\
\hline & Standardized RMR & 0.065 & $\leq 0,10$ & Fit \\
\hline 4 & GFI & 0.83 & $\geq 0,90$ & Tdk fit \\
\hline 5 & AGFI & 0.82 & $0.80 \leq$ AGFI $<0,9$ & Marjinal fit \\
\hline 6 & NFI & 0.87 & $\geq 0,90$ & Tdk fit \\
\hline 7 & NNFI & 0.90 & $\geq 0,90$ & Fit \\
\hline 8 & CFI & 0.90 & $\geq 0,90$ & Fit \\
\hline 9 & IFI & 0.90 & $\geq 0,90$ & Fit \\
\hline 10 & RFI & 0.86 & $\geq 0,90$ & Tdk fit \\
\hline 11 & PNFI & 0.83 & $\begin{array}{c}\text { tidak fit, semakin } \\
\text { besar semakin fit }\end{array}$ & Fit \\
\hline
\end{tabular}

Berdasarkan hasil analisis data diperoleh 8 kriteria yang memenuhi fit dan lebih banyak dibandingkan dengan yang tidak memenuhi (hanya 4) kriteria, sehingga model teoritis sesuai dengan data empiric (Fit).Kemudian, untuk melihat besarnya pengaruh indicator $\mathrm{H}-\mathrm{L}$ dalam membangun variabel Kemampuan Berfikir Kritis, maka koefisien gamma dari indicator H-L diperhatikan.

Berdasarkan hasil analisis data seperti yang disajikan pada Gambar 1.1 diatas, terlihat bahwa koofisien gamma untuk semua indicator tersebut masingmasing bernilai 0.75 yang berarti sumbangan pengaruh indikator $\mathrm{H}$ sebesar $75 \%$; Indikator I sebesar 82\% ; Indikator J sebesar 89\%; Indikator K sebesar 87\%; Indikator L sebesar 83\%. Hal tersebut menunjukkan bahwa kelima indicator yang 
membangun variabel Kemampuan Berfikir Kritis memiliki sumbangan atau pengaruh yang signifikan.

Setelah mengeluarkan butir yang tidak memenuhi criteria valid yaitu (butir 9; butir 11; butir 18; butir 23; butir 25; butir 31 dan butir 34 karena factor loading $<0.3$ (tidak dapat mengukur faktornya) maka selanjutnya dianalisis kembali dan hasil analisis dapat dilihat pada Gambar 1.2.

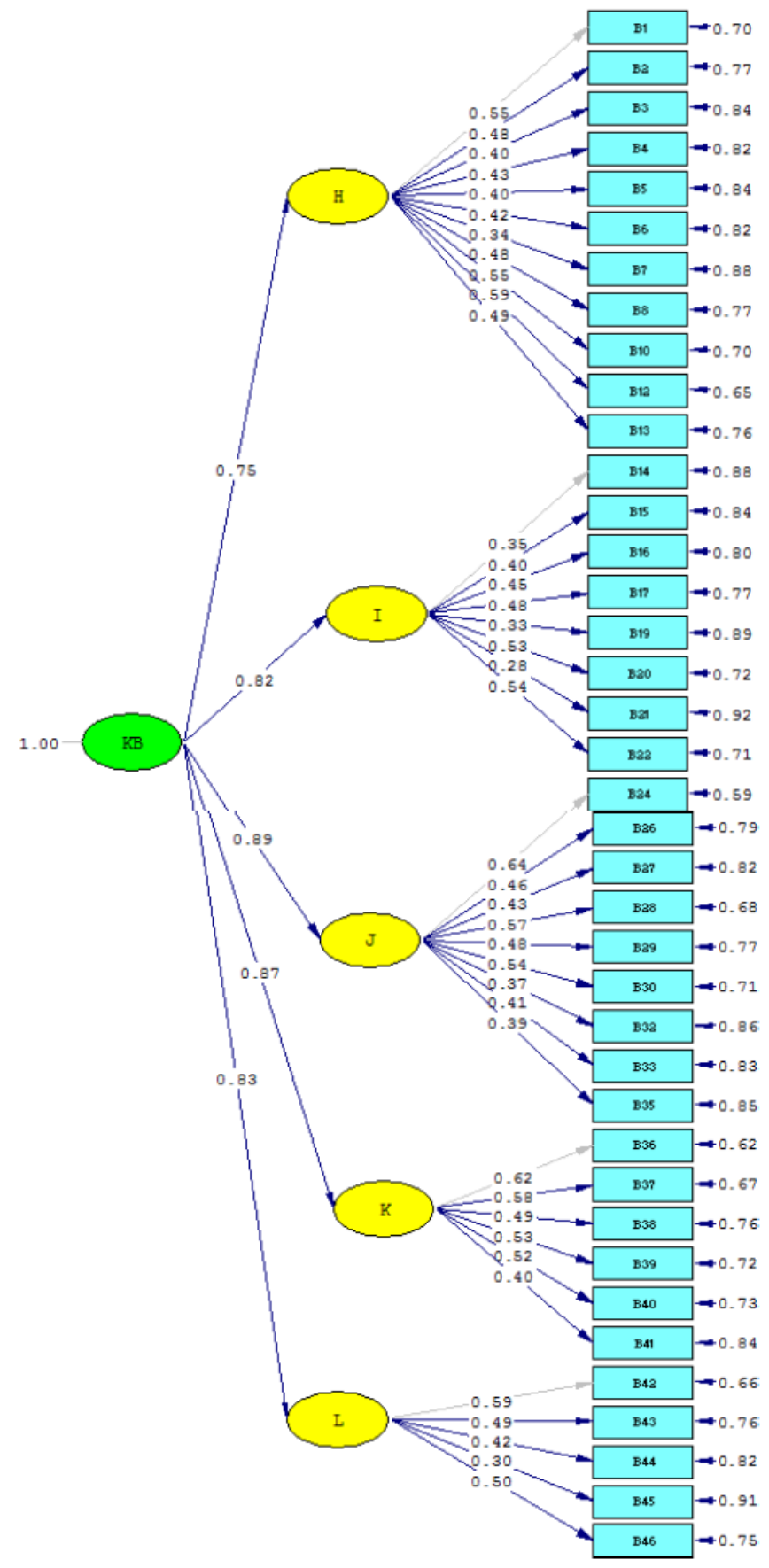




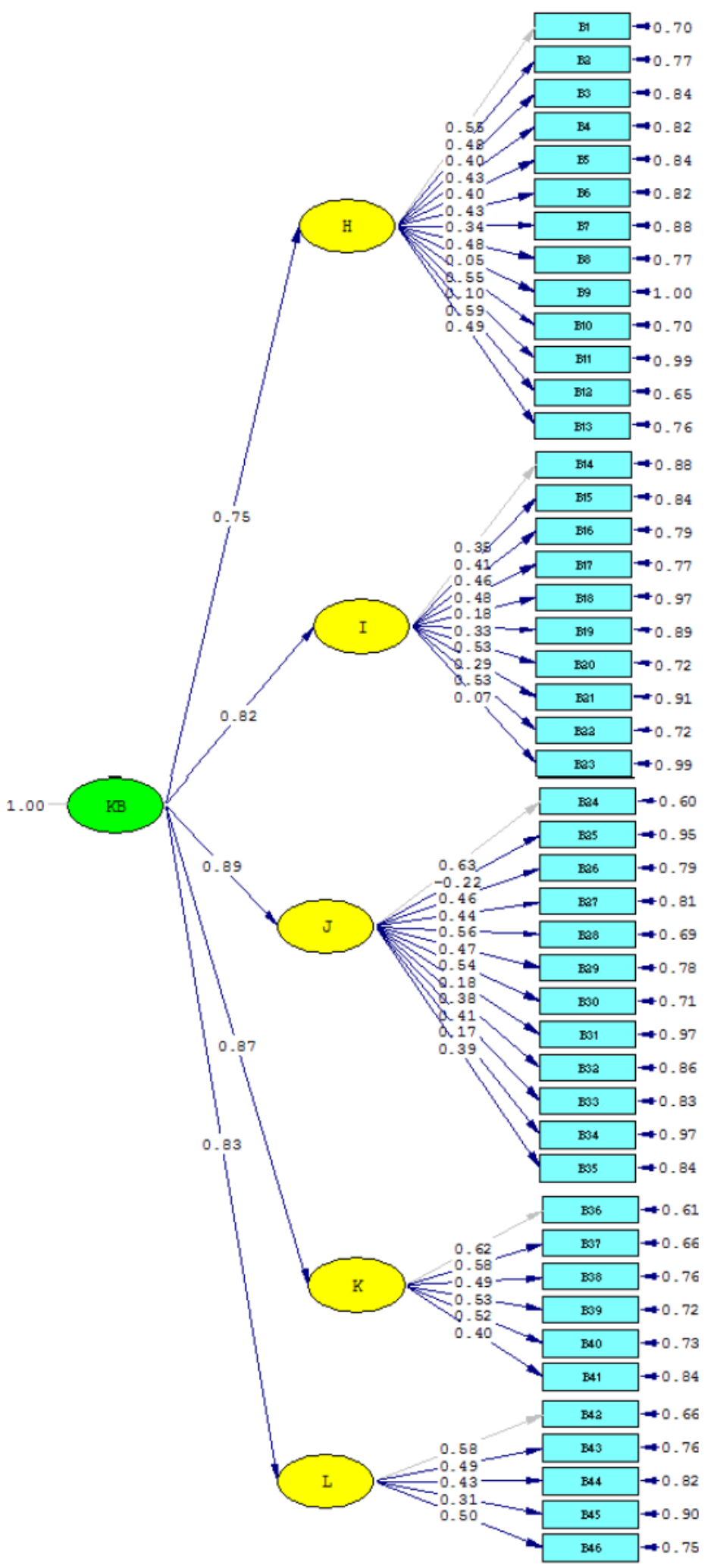

Gambar 1.2Nilai loading factor masing-masing indikator Analisis tahap II 
Mencermati informasi yang disajikan pada Gambar 1.2.tampak bahwa factor loading lebih besar dari 0,3 untuk setiap butir instrument yang membangun indicator H-L (Memberikan penjelasan sederhana, Membangun keterampilan dasar, Membuat inferensi, Memberikan penjelasan lebih lanjut, Mengatur strategi dan teknik). Dengan demikian semua butir memenuhi criteria valid untuk mengukur faktornya kecuali butir 21 yang harus direvisi karena memiliki loading factor 0,28 $(0.28<0.3)$. Kemudian tahapan berikutnya adalah menghitung reliabilitas instrument dengan menggunakan rumus (persamaan 4.1) yang dikemukakan oleh Geldhof, Preacher, dan Zyphur (2013:73):

$\omega=\frac{\left(\sum_{i=1}^{k} \lambda_{i}\right)^{2}}{\left(\sum_{i=1}^{k} \lambda_{i}\right)^{2}+\left(\sum_{i=1}^{k} \theta_{i i}\right)}$ 4.1

Keterangan:

$\omega=$ Koofisien Reliabilitas (Composite reliability)

$\lambda_{\mathrm{i}}=$ Loading Factor untuk setiap i yang membangun indicator

$\theta_{\mathrm{ii}}=$ Standard error untuk butir ke i

Berdasarkan hasil analisis seperti yang disajikan pada gambar 1.2 di atas dan untuk mempermudah perhitungan reliabilitas maka disajikan kembali data seperti pada Tabel 1.2.mencermati informasi yang disajikan pada Tabel 1.2 tersebut, maka nilai koofisien reliabilitas dihitung dengan menggunakan rumus persamaan 4.1 yaitu $\mathrm{CR}=0,92$. Nilai $\mathrm{CR}$ ini lebih besar dari nilai batas yang digunakan sebagai criteria yaitu 0,7Linn 1989 (Mansyur, 2009:134).

Tabel 1.2Hasil perhitungan Reliabilitas Instrument

\begin{tabular}{|c|c|c|c|c|c|c|c|c|c|c|c|c|c|c|c|c|c|c|c|c|c|}
\hline \multicolumn{22}{|c|}{ butir instrument } \\
\hline No & 1 & 2 & 3 & 4 & 5 & 6 & 7 & 8 & 10 & 12 & 13 & 14 & 15 & 16 & 17 & 19 & 20 & 21 & 22 & 24 & 26 \\
\hline$\lambda$ & 0,55 & 0,48 & 0,4 & 0,43 & 0,4 & 0,42 & 0,34 & 0,48 & 0,55 & 0,59 & 0,49 & 0,35 & 0,4 & 0,45 & 0,48 & 0,33 & 0,53 & 0,28 & 0,54 & 0,64 & 0,46 \\
\hline$\delta$ & 0,7 & 0,77 & 0,84 & 0,82 & 0,84 & 0,82 & 0,88 & 0,87 & 0,7 & 0,65 & 0,76 & 0,88 & 0,84 & 0,8 & 0,77 & 0,89 & 0,72 & 0,92 & 0,71 & 0,59 & 0,79 \\
\hline No & 27 & 28 & 29 & 30 & 32 & 33 & 35 & 36 & 37 & 38 & 39 & 40 & 41 & 42 & 43 & 44 & 45 & 46 & Jumlah & \multicolumn{2}{|c|}{ Jumlah^2 } \\
\hline$\lambda$ & 0,43 & 0,57 & 0,48 & 0,54 & 0,37 & 0,41 & 0,39 & 0,62 & 0,58 & 0,49 & 0,53 & 0,52 & 0,4 & 0,59 & 0,49 & 0,42 & 0,3 & 0,5 & 18,22 & \multicolumn{2}{|c|}{332} \\
\hline$\delta$ & 0,82 & 0,68 & 0,77 & 0,71 & 0,86 & 0,83 & 0,85 & 0,62 & 0,67 & 0,76 & 0,72 & 0,73 & 0,84 & 0,66 & 0,76 & 0,82 & 0,91 & 0,75 & 30,32 & & \\
\hline
\end{tabular}

Kemudian, untuk melihat besarnya pengaruh indicator $\mathrm{H}-\mathrm{L}$ dalam membangun variabel Kemampuan Berfikir Kritis, maka koefisien gamma dari indicator H-L diperhatikan. Berdasarkan hasil analisis data seperti yang disajikan pada Gambar 1.1 diatas, terlihat bahwa koofisien gamma untuk semua indicator tersebut masing-masing memiliki pengaruh sebesar 75\%; 82\%; 89\%; 87\%; dan 
83\% terhadap variable kemampuan berfikir kritis. Selanjutnya, dilakukan pemeriksaan pengaruh-pengaruh tersebut apakah signifikan atau tidak. Untuk keperluan tersebut perlu diperhatika output dalam bentuk t-values seperti pada Gambar 1.3.

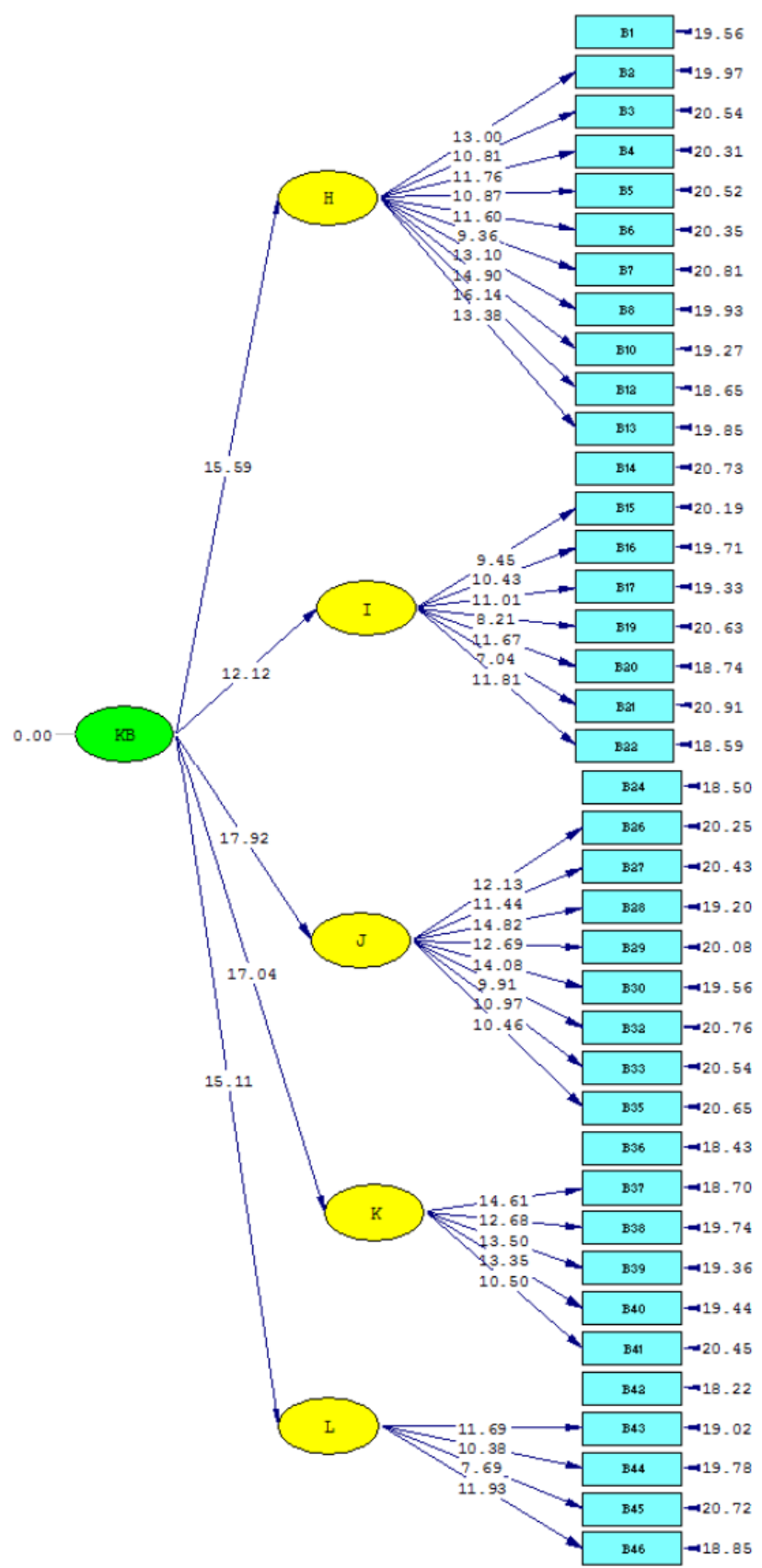

Gambar 1.3Nilai t-valuesmasing-masing indikator Analisis tahap II 
Merujuk hasil t-values seperti pada Gambar 1.3, tampak bahwa nilai thitung untuk masing-masing indicator H-L yaitu 15,59; 12,12; 17,92; 17,04; 15,11 berturut-turut. Nilai-nilai tersebut lebih besar dari nilai t-tabel pada taraf signifikansi $\alpha=0,05$ dan derajat bebas 927 (n-1) sebesar 1,960. Hal tersebut menunjukkan bahwa pengaruh masing-masing indicator tersebut terhadap Kemampuan berfikir kritis signifikan.

Sedangkan uji Model untuk tahap kedua ini juga secara teoritis telah sesuai dengan data empiris dan Criteria untuk menguji Goodness of Fit model tetap menggunakan statistic RMSEA, PNFI dan IFI dan hasil analisis disajikan pada Tabel 1.3.

Tabel 1.3.Statistic dan Criteria fit Model

\begin{tabular}{|c|c|c|c|c|}
\hline No. & Statistik & $\begin{array}{c}\text { Hasil } \\
\text { perhitungan }\end{array}$ & Kriteria 'fit” & Keterangan \\
\hline 1 & $\begin{array}{c}\text { Minimum fit function } \\
\text { chi-square }\left(\chi^{2}\right)\end{array}$ & $\begin{array}{c}2231.07 \\
(\mathrm{P}=0.0)\end{array}$ & $\mathrm{p}>0.05$ & Tdk fit \\
\hline 2 & RMSEA & 0.052 & $<0.08$ & Fit \\
\hline 3 & $\begin{array}{c}\text { Root Mean Square } \\
\text { Residual (RMR) }\end{array}$ & 0.038 & $\leq 0,10$ & Fit \\
\hline & Standardized RMR & 0.060 & $\leq 0,10$ & Fit \\
\hline 4 & GFI & 0.88 & $\geq 0,90$ & Tdk fit \\
\hline 5 & AGFI & 0.86 & $0.80 \leq$ AGFI $<0,9$ & Marjinal fit \\
\hline 6 & NFI & 0.90 & $\geq 0,90$ & Fit \\
\hline 7 & NNFI & 0.93 & $\geq 0,90$ & Fit \\
\hline 8 & CFI & 0.93 & $\geq 0,90$ & Fit \\
\hline 9 & IFI & 0.93 & $\geq 0,90$ & Fit \\
\hline 10 & RFI & 0.90 & $\geq 0,90$ & Fit \\
\hline 11 & PNFI & 0.85 & $\begin{array}{c}0: \text { tidak fit, semakin } \\
\text { besar semakin fit }\end{array}$ & Fit \\
\hline
\end{tabular}

Berdasarkan hasil analisis data diperoleh bahwa lebih banyak yang memenuhi criteria fit dibandingkan dengan yang tidak memenuhi yaitu 10 yang memenuhi criteria fit sedangkan hanya 2 yang tidak memenuhicriteria fit, sehingga model teoritis sesuai dengan data empiric (Fit).

\section{E. Simpulan}

Berdasarkan hasil-hasil penelitian dan Pembahasan yang ditampilkan sebelumnya, maka maka dapat disimpulkan bahwa instrument kemampuan 
berfikir kritis memenuhi criteria validitas, reliabilitas dan serta model secara teoritis sesuai dengan data empiris (Goodness of Fit model).

\section{Daftar Pustaka}

Azwar, Saifuddin. 1996. Tes Prestasi. Fungsi dan Pengembangan Pengukuran Prestasi Belajar. Yogyakarta: Pustaka Pelajar.

Cindy L. Lynch and Susan K. Wolcott, 2001.Helping Your Students Develop Critical Thinking Skills. WolcottLynch Associates.www.theideacenter.org.

Ennis, Rober H. 1993. Critical thinking assessment. Theory into practice, volume 32, Number 3, summer 1993. Copyright 1993 collage of education. The ohio state university.

Fithriyah, I., Sa'dijah, C., \& Sisworo.(2016). Analisis Kemampuan Berpikir Kritis Siswa Kelas IX-D SMPN 17 Malang. Prosiding ISSN: 2502-6526, (Knpmp I), 580-590.

Geldhof, Preacher, dan Zyphur. 2013. Reliability Estimation in a Multilevel Confirmatory Factor Analysis Framework. Journal of Psychological Methods 2014, Vol. 19, No. 1, 72-91. Diakses 14 Juni 2016 pada http://quantpsy.org/pubs/geldhof_preacher_zyphur_2014.pdf

Havelock, R.G. (1976). Planning for Innovation through Dissemination and Utilization of Knowledge. Institute for Social Research The University ofMichigan.

Hair, J. F., Black, W. C., Babin, B. J., \& Anderson, R. E. (2010). Multivariate data analysis: A global perspective (seventh ed). New Jersey: Pearson Education, Inc.

Krulik, S \& Rudnick.1999." Innovative Taks to Improve Critical and Creative Thinking Skills. Develoving Mathematical Raesoning in Grades K-12”, pp.138-145.

Moore, B.N \& Parker, R. 1986.Critical Thinking Evaluating and Arguments in Everyday Life.California State University. California: Mayfield Publishing Company.

Mansyur,. Rasyid, Harun,.\& Suratno. 2009. Assesmen Pembelajaran di Sekolah. Yogyakarta: Multi Pressindo.

Muljono, Pudji \& Djaali. 2008. Pengukuran dalam Bidang Pendidikan. Jakarta: Grasindo.

Nitko, Anthony J,.\& Brookhart, Susan M. 2007.Educational Assessment Of Students. New Jersey: Pearson Education.

Perkins, C., \& Murphy, E. (2006).Identifying and measuring individual engagement in critical thinking in online discussions: An exploratory case study. Educational Technology \& Society, 9 (1), 298-307.

Robert J.Marzano, S.Brandt, R., Hughes, C. S., Jones, B. F., Z.Presseisen, B., C.Ranking, S., \& Suhor, C. (1988).Dimensions of thinking:a framework for curriculum and instruction. Philadelphia: ERIC Clearinghouse on Reading and Communication Skills. 
Ruggiero, Vincent R. 1998. The Art of Thinking.A Guide to Critical and Creative Thought.New York: Longman, An Imprint of Addison Wesley Longman, Inc.

Sudrajat, Ahmad. 2008. Pengembangan Perangkat Penilaian Psikomotor.(http://akhmadsudrajat.files.wordpress.com/2008/08/penilaianpsikomotor.pdf, diakses pada 10 Juli 2017).

Widhiarso, Wahyu, 2012. Mengestimasi Reliabilitas. (http://widhiarso.staff.ugm.ac.id/files/bab_2_estimasi_reliabilitas_via_spss .pdf, diakses pada 12 Juli 2017). 